\title{
A simple assay for chitin: application to sediment trap samples from the subarctic Pacific
}

\author{
Michael T. Montgomery ${ }^{1}$, Nicholas A. Welschmeyer ${ }^{2}$, David L. Kirchman ${ }^{1}$ \\ ${ }^{1}$ College of Marine Studies, University of Delaware, Lewes, Delaware 19958, USA \\ ${ }^{2}$ Moss Landing Marine Laboratory, Moss Landing, California 95039-0450, USA
}

\begin{abstract}
Chitin is thought to be abundant in marine environments, but examination of the role of chitin in nutrient cycling has been hampered by the lack of an adequate assay for measuring concentrations at ambient levels. We developed a simple assay using the lectin, wheat germ agglutinin (WGA), which has an affinity for the $\mathrm{N}$-acetylglucosamine (NAG) residues found in chitin. The specificity of the assay was confirmed by enzymatic hydrolysis with chitinase and competitive inhibition with chitotriose. The lectin bound specifically to chitin even when samples contained high concentrations of cellulose, clay, and bacteria. Concentrations of suspended chitin were 4 to $21 \mu \mathrm{g} 1^{-1}$ in Delaware Bay, USA, and 4 to $10 \mu \mathrm{g} \mathrm{l^{-1 }}$ in the subarctic Pacific. The assay was also applied to sediment trap samples collected in the subarctic Pacific. We found that the chitin flux accounted for less than $1 \%$ of carbon and nitrogen fluxes above $500 \mathrm{~m}$. Using fluorescently-labelled WGA and epifluorescence microscopy, we were able to differentiate detritus, zooplankton fecal pellets and possibly fungi from nonchitinous particles.
\end{abstract}

\section{INTRODUCTION}

Chitin, which is a polymer of $\mathrm{N}$-acetylglucosamine (NAG), rivals cellulose as the most abundant biopolymer in nature. Unlike cellulose, chitin can be a source of nitrogen as well as carbon ( $\mathrm{C}: \mathrm{N}=8: 1)$. Planktonic crustaceans have been considered the most significant source of chitin in the marine environment, and global estimates of chitin in marine environments were based on the chitin content of copepods and copepod abundance (Johnstone 1908). Of greater consequence to these global estimates could be the finding that copepod fecal pellets are encased in chitin (Yoshikoshi \& Ko 1988). In addition, several common genera of diatoms, such as Thalassiosira and Skeletonema, produce chitin as a significant portion (up to $33 \%$ ) of their biomass (Smucker \& Dawson 1986). These diatoms synthesize chitin strands that extent outside their frustules to increase buoyancy (McLachlan et al. 1965). Given these findings, current global estimates of chitin concentrations are probably conservative.

There are at least 2 general roles possible for chitin in carbon and nitrogen cycles of marine ecosystems. First, chitin may be an important carbon and nitrogen source for heterotrophic bacteria. Second, chitin may contribute to or be associated with the flux of material from the mixed layer zone to the deep ocean. Large detrital particles $(>100 \mu \mathrm{m})$ are thought to account for much of the removal of carbon and nitrogen from the mixed layer (Fowler \& Knauer 1986). Zooplankton fecal pellets and exoskeletons, which are chitinaceous, can comprise a substantial portion of these large particies (Fowler \& Knauer 1986). Obtaining accurate estimates of chitin concentrations is the first step in evaluating the possible importance of chitin in nutrient cycles.

Chitin has been measured in sediments after acid and alkali treatment with subsequent degradation by chitinases and colorimetric measurement of NAG (Jeuniaux et al. 1982, Poulicek \& Jeuniaux 1982). According to this approach, chitin was less than $0.2 \mathrm{mg}$ $\mathrm{g}^{-1}$ of decalcified material for most Mediterranean sediments (Jeuniaux et al. 1982, Poulicek \& Jeuniaux. 1982). However, chitin assays relying on chitinase may underestimate chitin concentrations because chitinase may be ineffective in complex environmental samples with low chitin concentrations. Chemical hydrolysis of a sample with subsequent measurement of NAG would not measure chitin specifically because bacterial cell walls have large amounts of NAG. Also, colorimetric measurement of NAG is relatively insensitive and measures other hexosamines in addition to NAG (Reissig et al. 1955). Unacetylated glucosamine has 
been measured (using high performance liquid chromatography) in hydrolyzed sediment trap samples and then related to chitin (Muller et al. 1986). Unacetylated glucosamine, however, is actually the monomeric unit of chitosan, not chitin. Glucosamine concentration may underestimate total chitin because diatom chitin is fully acetylated (McLachlan et al. 1965) and the degree of acetylation of chitin in zooplankton fecal pellets is unknown. Chitin suspended in seawater has not been examined.

The importance of chitin in marine environments cannot be extensively examined unless it can be easily measured in naturally-occurring quantities. We discuss here one possible method. Wheat germ agglutinin (WGA) is a sugar-binding protein (lectin) that binds to a series of 3 consecutive NAG residues (Allen et al. 1973, Roth 1978). This lectin has been used extensively in histological work to localize chitin (Tronchin et al 1981, Greven \& Peters 1986, Peters \& Latka 1986). We developed a method using FITC- and ${ }^{3} \mathrm{H}$-labelled WGA and applied the method to samples taken from the Delaware Bay (USA) and from sediment traps in the subarctic Pacific.

\section{MATERIALS AND METHODS}

Measuring chitin with WGA. Chitin was measured by fluorometry using fluorescein isocyathionate-labelled (FITC) WGA or by a radioassay using ${ }^{3} \mathrm{H}$-WGA. Delaware Bay seawater and sediment trap samples (100 to $200 \mathrm{ml}$ ) from the subarctic Pacific were concentrated to $3 \mathrm{ml}$ using $1.0 \mu \mathrm{m}$ Nuclepore polycarbonate filters. Seawater samples (1 l) from the subarctic Pacific were filtered through Whatman GF/F filters (diam. $25 \mathrm{~mm}$ ). Adsorption of WGA to filters was subtracted from sample values to account for nonspecific binding. The GF/F filters had higher nonspecific binding of the WGA than the polycarbonate filters $(0.3$ to 0.5 vs $0.1 \mu \mathrm{g})$. Prior to assay for chitin, the GF/F filters with chitin samples were cut up into 8 pieces and added to a glass scintillation vial with $3 \mathrm{ml}$ of phosphate or borate buffer (10 mM; pH 7.4). The assay works equally well in filtered $(0.2 \mu \mathrm{m})$ seawater instead of buffer. Plastics should be avoided because WGA can bind to these materials. Concentrated samples should be frozen for long-term storage. Because formaldehyde (1\%) inhibits WGA binding to chitin, sodium azide $(0.2 \%)$ should be used to prevent bacterial growth during time course experiments. For all standard curves, chitin purified from crab shell (Sigma) was used.

In the fluorometric assay, fluorescence intensity in the filtrate (WGA not binding to chitin) is inversely correlated with chitin concentration in the sample when there is excess FITC-WGA. FITC-labelled suc-
cinylated-WGA (20 $\mu g_{\text {; }}$ Vector Laboratories, Inc.) was added to the buffer containing the chitin particles $(30 \mu \mathrm{g}$ or less). If the samples contain more than $50 \mu \mathrm{g}$ of chitin, more WGA must be added to maintain a linear relationship between chitin concentration and binding of WGA. Samples with more than $50 \mu \mathrm{g}$ of chitin should probably be diluted to avoid using excessive amounts of WGA (>30 $\mu \mathrm{g}$ of WGA sample ${ }^{-1}$ ). After incubation $\left(30 \mathrm{~min} ; 25^{\circ} \mathrm{C}\right)$ on a shaker table $(130 \mathrm{rpm})$, samples were filtered $(0.2 \mu \mathrm{m}$ Nuclepore polycarbonate filters) and rinsed twice with fresh buffer The filtrate was measured for unbound FITCWGA with a Turner fluorometer using a general bulb (Turner; 110-850) as a light source, $2 \mathrm{~A}$ and $47 \mathrm{~B}$ as primary filters (425 to $525 \mathrm{~nm}$ ) and $2 \mathrm{~A}-13$ as a secondary filter $(>510 \mathrm{~nm})$.

When using the radioassay, the amount of radioactivity bound to the chitin particles on the filter is directly correlated with the amount of chitin present in the sample. Succinylated WGA (Monsigny et al. 1979) was radiolabelled with ${ }^{3} \mathrm{H}$-borohydride $\left(\mathrm{NaB}^{3} \mathrm{H}_{4}\right.$ ) (Tack et al. 1980). The WGA solution (2 $\mathrm{mg}$ in $200 \mu$ l of $0.2 \mathrm{M}$ borate buffer, $\mathrm{pH}$ 8.9) was mixed with the $\mathrm{NaB}^{3} \mathrm{H}_{4}$ $(0.5 \mathrm{mCi})$ and $0.1 \mathrm{M}$ formalin $(20 \mu \mathrm{l})$ and incubated on ice for $10 \mathrm{~min}$. The ${ }^{3} \mathrm{H}$-WGA was then rinsed 4 times with $1 \mathrm{ml}$ of borate buffer using Centricon 10 protein concentrators (Amicon). When measuring $15 \mu \mathrm{g}$ of chitin or less, $10 \mu \mathrm{g}$ of ${ }^{3} \mathrm{H}$-WGA (specific activity: $1.82 \mu \mathrm{Ci}$ $\mathrm{mg}^{-1}$; see below) was added to the concentrated chitin sample $(3 \mathrm{ml})$ and incubated $\left(30 \mathrm{~min} ; 25^{\circ} \mathrm{C}\right)$ on a shaker table $(130 \mathrm{rpm})$. The samples were then filtered $(0.20 \mu \mathrm{m}$ Nuclepore polycarbonate) and rinsed 3 times with $5 \mathrm{ml}$ of buffer. The filters were then radioassayed and the radioactivity on the filter was converted to $\mu \mathrm{g}$ of ${ }^{3} \mathrm{H}$-WGA bound to particles by using the specific activity of the ${ }^{3} \mathrm{H}$-WGA. Amount of radioactivity on the filter was directly proportional to chitin concentration in the sample when an excess of ${ }^{3} \mathrm{H}$-WGA was used.

WGA specificity for chitin. The binding of a lectin to a polysaccharide is competitively inhibited by low molecular-weight sugars (Sharon \& Lis 1972). The specificity of WGA for chitin (a structural polysaccharide consisting of poly-NAG) was determined using low molecular weight sugars, including the monomer of chitin (NAG), dimer (chitobiose), and trimer (chitotriose). Inhibitor concentrations ranging from 5 to $100 \mathrm{nM}$ (final sample concentration) were tested. Nonspecific binding of WGA to common particles in seawater samples was determined using cellulose (Sigmacell Type 20 microcrystalline: $20 \mu \mathrm{m}$ ) and clay particles (kaolin) (Sigma: 0.1 to $4 . \mathrm{um}$ ).

Strains of Gram-positive and Gram-negative bacteria were assayed to examine possible interference in chitin measurements. The Gram-negative strain tested was Vibrio harveyi (ATCC \# 14126) grown up in LM broth 
$\left(\mathrm{NaCl}, 20 \mathrm{gl}^{-1}\right.$; tryptone, $10 \mathrm{gl}^{-1}$; yeast extract, $5 \mathrm{~g} \mathrm{l}^{-1}$ ). Cultures were centrifuged and washed with sterile seawater 4 times before diluting to appropriate concentration. The Gram-positive strain tested, Micrococcus lysodeikticus (Sigma; lyophilized), was resuspended and diluted to appropriate concentrations with seawater. Binding of FITC-WGA to the bacterial strains was examined with epifluorescence microscopy (see below).

Specificity of ${ }^{3} \mathrm{H}$-WGA for chitin particles in sediment trap samples was examined by comparing ${ }^{3} \mathrm{H}$-WGA binding with and without addition of chitotriose $(10 \mathrm{mM})$. Sediment trap samples were measured with and without chitinase pretreatment to determine how much of the particulate chitin that binds WGA can also be solubilized by chitinase. Chitinase (Sigma: 4 units sample ${ }^{-1}$ ) was added to samples and incubated for $3 \mathrm{~h}$ on a shaker table $\left(130 \mathrm{rpm} ; 25^{\circ} \mathrm{C}\right)$.

Specificity of WGA for chitin was also confirmed using FITC-WGA and epifluorescence microscopy. Cellulose, purified chitin particles, bacteria, and samples $(5 \mathrm{ml})$ from the sediment traps (exposed for $3 \mathrm{~h}$ ) were stained with $20 \mu \mathrm{g}$ FITC-WGA for $30 \mathrm{~min}$ $\left(130 \mathrm{rpm} ; 25^{\circ} \mathrm{C}\right)$ and filtered onto $0.2 \mu \mathrm{m}$ Nuclepore filters (prestained with Irgalan black). The samples were rinsed 3 times with borate buffer and then observed using epifluorescence microscopy (Olympus BH-2 microscope; $490 \mathrm{~nm}$ excitation, $515 \mathrm{~nm}$ emission).

Chitin concentration in Delaware Bay. Surface water samples were taken from a dock in Roosevelt Inlet, Lewes, Delaware, USA. The Roosevelt Inlet receives waters from the Broadkill River and the Lewes-Rehoboth Canal, and is located ca $4 \mathrm{~km}$ inside the mouth of the Delaware Bay. Samples (0.2 to 1 l) were concentrated to $3 \mathrm{ml}(1.0$ um Nuclepore polycarbonate filters) prior to assay with WGA. After concentration, some samples were extracted with $10 \%$ (final conc.) of hot $\left(95^{\circ} \mathrm{C}\right)$ trichloroacetic acid (TCA) for $10 \mathrm{~min}$ to remove non-chitinous materials that may interfere with the assay. However, chitin concentrations measured before and after TCA extraction were the same.

Primary production and sediment traps. Primary production in the subarctic Pacific at Stn $\mathrm{P}\left(50^{\circ} \mathrm{N}\right.$, $150^{\circ} \mathrm{W}$ ) was measured by ${ }^{14} \mathrm{CO}_{2}$ uptake measurements with in situ incubations (Parsons et al. 1984). Water at various depths (normally every 10 to $80 \mathrm{~m}$ ) in the euphotic zone was collected before dawn using Go-Flo bottles. After addition of $\mathrm{NaH}^{14} \mathrm{CO}_{3}$, polycarbonate incubation bottles (4l) were returned to depth and incubated for $24 \mathrm{~h}$ (dawn to dawn). Rates of areal primary production were calculated by integrating volumetric rates over the euphotic zone.

Sediment traps were spaced throughout the upper $500 \mathrm{~m}$ water column on floating trap arrays (Lorenzen et al. 1983, Welschmeyer \& Lorenzen 1985) and deployed normally for $3 d$, although there was one experiment with a $3 \mathrm{~h}$ deployment. Sediment traps were closed by electronic messenger release and retrieved for sampling. (The short $3 \mathrm{~h}$ exposure was the result of an accidental early messenger release.) The sampling depths were concentrated in the upper ocean to measure the particulate flux immediately leaving the euphotic zone. Trap exposures were short to minimize decomposition (Lorenzen et al. 1983, Knauer et al. 1984). Samples were sieved with $500 \mu \mathrm{m}$ mesh to remove whole zooplankton that might have swum into the traps. Sediment trap samples $(200 \mathrm{ml})$ were frozen prior to concentration and assay for chitin. Subsamples $(5 \mathrm{ml})$ from some sediment traps were stained with FITC-WGA and observed using epifluorescent microscopy to determine what materials were being measured by the chitin assay.

Samples from sediment traps for carbon and nitrogen analysis were collected on $25 \mathrm{~mm}$ Whatman GF/F filters, dried at $60^{\circ} \mathrm{C}$, and stored under vacuum in a desiccator. Prior to analysis, samples were placed in perforated plastic holders (Tissue Teks) and fumed over concentrated $\mathrm{HCl}$ for $12 \mathrm{~h}$ to remove inorganic carbonate. The samples were dried again at $60^{\circ} \mathrm{C}$ and analyzed on a Perkin-Elmer $240 \mathrm{C} \mathrm{CHN}$ analyzer using acetanilide as a standard

\section{RESULTS}

\section{Optimal assay conditions}

Assay conditions were examined to maximize sensitivity and to minimize time and expense. These conditions included: wheat germ agglutinin (WGA) concentration, sample agitation, and incubation time. When chitin concentrations were less than $50 \mu \mathrm{g} \mathrm{sam-}$ $\mathrm{ple}^{-1}, 20 \mu \mathrm{g}$ of WGA was in excess. When chitin concentration was less than $10 \mu \mathrm{g}$ sample ${ }^{-1}, 10 \mu \mathrm{g}$ of WGA was used. WGA binding was highest when samples were shaken at $130 \mathrm{rpm}$ for $30 \mathrm{~min}$. Under these conditions, the detection limit with FITC-WGA for chitin was $3 \mu \mathrm{g}$ per $3 \mathrm{ml}$ sample (mean fluorescence for $3 \mu \mathrm{g}$ was one standard deviation higher that the blank) (Fig. 1A). The detection limit with ${ }^{3} \mathrm{H}$-WGA was $1 \mu \mathrm{g}$ of chitin $\left({ }^{3} \mathrm{H}\right.$-WGA binding was 2 -fold higher than the blank) (Fig. 1B). Sodium azide $(0.2 \%$ was used in samples during $3 \mathrm{~h}$ chitinase degradation experiments (see below) to suppress bacterial growth.

\section{Specificity of assay}

Because WGA binds to 3 consecutive NAG residues, chitotriose (the trimer sugar of NAG) is often used as a 

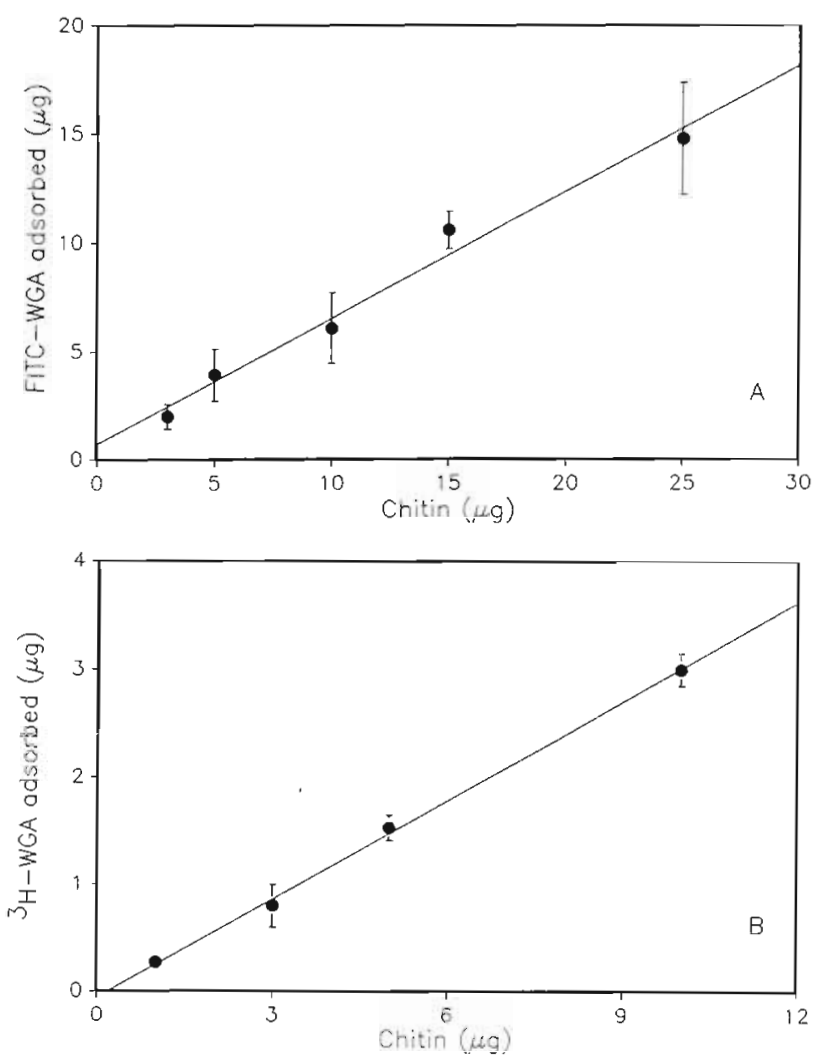

Fig. 1. WGA binding versus chitin concentration. (A) Standard curve with FITC-WGA. (B) Standard curve with ${ }^{3} \mathrm{H}$-WGA

competitive inhibitor of WGA (Greven \& Peters 1986). WGA binding to chitin was slightly inhibited by $1 \mathrm{nM}$ chitotriose and almost completely inhibited by $100 \mathrm{nM}$ (Fig. 2). NAG and chitobiose had no significant effect on WGA binding to chitin particles (Fig. 2). NAG did partially inhibit WGA binding ( $25 \%$ of control) at concentrations $10^{6}$-fold higher $(10 \mathrm{mM})$ than those used with chitotriose $(10 \mathrm{nM})$ (data not shown). Based on these competitive inhibition experiments, WGA appears specific for chitin in seawater.

Cellulose and clay (kaolin) may be abundant in some marine environments. Even relatively low binding of WGA to these materials could interfere with chitin measurements because chitin concentrations may be lower than those of cellulose or clay. However, binding was minimal ( $5 \%$ or less of added WGA) even at the highest cellulose concentrations tested (150 ug per $3 \mathrm{ml}$ sample; Fig. 3). Only at extremely high kaolin concentrations (>1 mg per $3 \mathrm{ml}$ sample) was there measurable binding of WGA onto these particles (Fig. 4). Addition of bovine serum albumin $(100 \mu \mathrm{g})$ eliminated adsorption of WGA to kaolin particles (Fig.4), presumably by blocking nonspecific sites that bind any protein

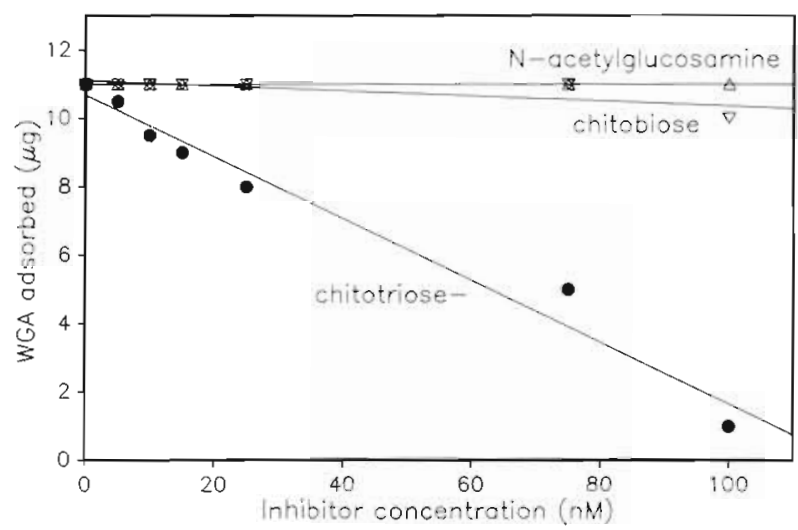

Fig. 2. Competitive inhibition of FITC-WGA binding to chitin by chitotriose, chitobiose and $\mathrm{N}$-acetyl-D-glucosamine

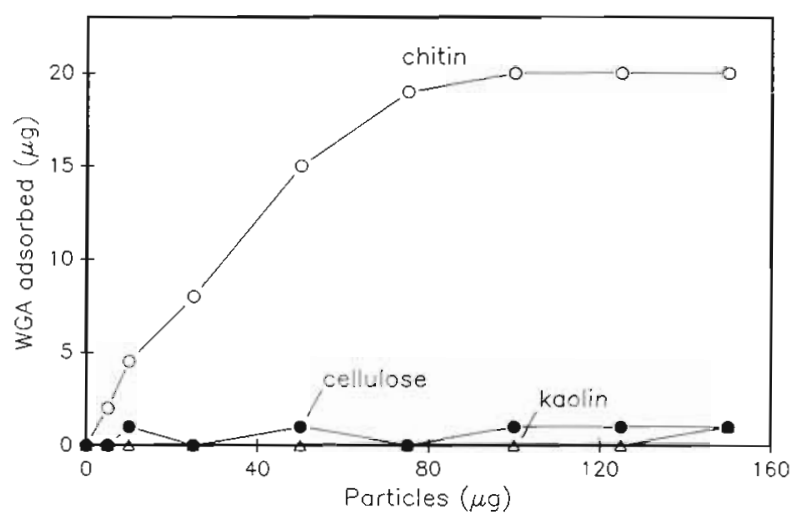

Fig. 3. Binding of FITC-WGA to chitin in the presence of cellulose and kaolin at particle concentrations up to $150 \mu \mathrm{l}$ per $3 \mathrm{ml}$ concentrated sample

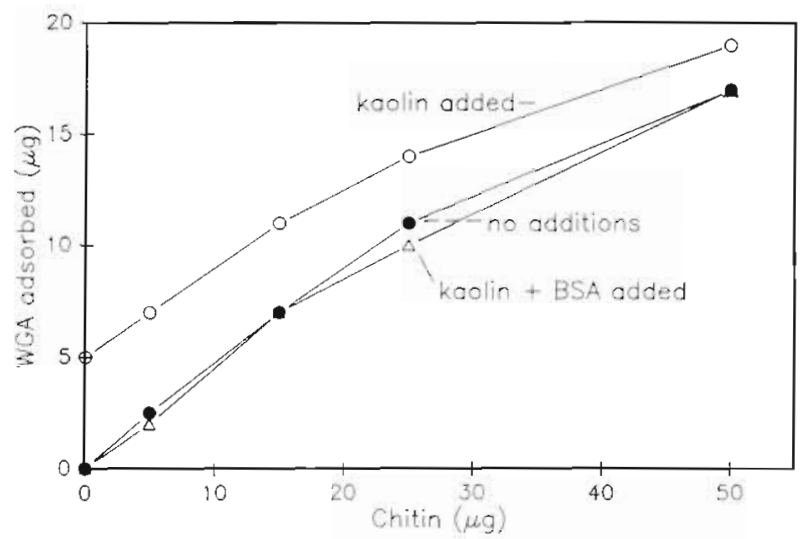

Fig. 4. Binding of FITC-WGA to chitin ( $3 \mathrm{ml}$ sample) in the presence of kaolin $(10 \mathrm{mg})$ with and without the addition of $100 \mu \mathrm{g}$ of bovine serum albumin (BSA)

Environmental samples also include bacteria whose cell walls contain substantial amounts of NAG residues in peptidoglycan. WGA did not measurably bind to Vibrio harveyi (Gram-negative) nor to Micrococcus lysodeikticus (Gram-positive) even at bacterial concen- 
trations greater than $10^{7}$ cells $\mathrm{ml}^{-1}$. This observation was confirmed using FITC-WGA stained particles and epifluorescent microscopy. Pure cultures of marine bacteria and natural bacterial assemblages stained poorly with FITC-WGA, in contrast to chitin particles which stained intensely.

\section{Chitin concentrations in Delaware Bay}

Chitin concentrations were measured in surface waters nearshore in the Delaware Bay during the latter part of 1987 . The samples were concentrated from 200

Table 1. Chitin concentrations ( $\mu \mathrm{g} \mathrm{l}^{-1}$ ) in Roosevelt Inlet, (Delaware Bay system) in 1987. Standard deviation (SD) and number of samples given parenthetically. For August samples, particles $(>1.0 \mu \mathrm{m})$ were first concentrated and then divided into subsamples. For other dates, subsamples were taken directly from the inlet

\begin{tabular}{|ccc|}
\hline Date & $\begin{array}{c}\text { Chitin concen- } \\
\text { tration }\left(\text { ug l }^{-1}\right)\end{array}$ & SD (n) \\
\hline 7 Aug & 4 & $0.8(3)$ \\
9 Aug & 10 & $3.6(5)$ \\
12 Aug & 13 & $3.3(9)$ \\
1 Sep & 21 & $1.4(2)$ \\
22 Sep & 13 & $0.4(5)$ \\
30 Nov & 5 & $0.4(3)$ \\
10 Dec & 6 & $0.3(4)$ \\
\hline
\end{tabular}

to $3 \mathrm{ml}$ using a Nuclepore filter $(1.0 \mu \mathrm{m})$. Chitin concentrations ranged from $21 \mu \mathrm{g} \mathrm{l}^{-1}$ in September to $5 \mu \mathrm{g} \mathrm{l}^{-1}$ in late November and December (Table 1).

\section{Chitin flux in subarctic Pacific}

Chitin was measured in sediment traps from the Gulf of Alaska. In September 1987, the chitin flux at $60 \mathrm{~m}$ was $4.4 \mathrm{mg}$ chitin $\mathrm{m}^{-2} \mathrm{~d}^{-1}$ when primary production was high (1338 $\mathrm{mg} \mathrm{C} \mathrm{m}^{-2} \mathrm{~d}^{-1}$ ) and $1.3 \mathrm{mg}$ chitin $\mathrm{m}^{-2}$ $\mathrm{d}^{-1}$ when primary production decreased (389 mg C $\mathrm{m}^{-2} \mathrm{~d}^{-1}$ ) (Table 2).

WGA specificity for chitin in the sediment traps was examined using competitive inhibition by amino sugars and enzymatic degradation by chitinase (Table 2). Chitotriose $(10 \mathrm{mM})$ completely inhibited binding of WGA to the sediment trap samples and the purified chitin control, further demonstrating the specificity of WGA for chitin in these samples. After $3 \mathrm{~h}$, the chitinase hydrolyzed $3 \mu \mathrm{g}$ of chitin from both the purified chitin control and sediment trap sample from the high production station. Chitinase treatment of the sediment trap sample from the low production station did not reduce WGA binding (Table 2 ).

Chitin was also measured in sediment traps in August 1988. The chitin flux decreased by $87 \%$ with depth, from $11.2 \mathrm{mg} \mathrm{m}^{-2} \mathrm{~d}^{-1}$ at $10 \mathrm{~m}$, to $5.9 \mathrm{mg} \mathrm{m}^{-2} \mathrm{~d}^{-1}$ at $50 \mathrm{~m}$, to $1.5 \mathrm{mg} \mathrm{m}^{-2} \mathrm{~d}^{-1}$ at $70 \mathrm{~m}$ (Fig. $5 \mathrm{~A}$ ). From 70 to $500 \mathrm{~m}$, the chitin flux varied little, ranging from 1.3 to $1.8 \mathrm{mg} \mathrm{m} \mathrm{m}^{-2} \mathrm{~d}^{-1}$. The carbon flux decreased similarly with depth. Chitin flux accounted for less than $1.0 \%$ of the total carbon and nitrogen flux below $30 \mathrm{~m}$ (Fig. 5B).

Concentrations of suspended chitin were measured from 11 samples taken at the same time and depth as the sediment trap samples and were compared with concentrations in the sediment traps. Suspended chitin concentrations varied from $10.6 \mu \mathrm{g} \mathrm{l}^{-1}$ at $30 \mathrm{~m}$ to $<5.0 \mu \mathrm{g} \mathrm{l}^{-1}$ below $60 \mathrm{~m}$ (Fig. 6). Concentrations of suspended chitin were an order of magnitude lower than those measured for the upper sediment trap samples, indicating that chitin flux measurements were not simply the result of suspended chitin caught in the traps. As expected, the chitin concentrations in the sediment trap samples that were deployed for a short time (ca 3 h) were only slightly greater than the concentrations of suspended chitin (Fig. 6).

\section{Examination of samples with FITC-WGA and epifluorescence microscopy}

Sediment trap samples ( $3 \mathrm{~h}$ deployment) were stained with FITC-WGA and observed with epifluo-

Table 2. Chitin in sediment traps from the subarctic Pacific during 1987

\begin{tabular}{|c|c|c|c|c|c|}
\hline Sample & $\begin{array}{l}\text { Primary production } \\
\qquad\left(\mathrm{mgC}^{-2} \mathrm{~d}^{-1}\right)\end{array}$ & $\begin{array}{l}\text { Chitin flux } \\
\left(m g m^{-2} d^{-1}\right)\end{array}$ & $\begin{array}{l}\text { Initial chitin } \\
\qquad(\mu g)\end{array}$ & $\begin{array}{l}\text { Chitin degraded } \\
(\mu \mathrm{g})^{\mathrm{b}}\end{array}$ & $\begin{array}{l}\text { \% Inhibited by } \\
\text { chitotriose }\end{array}$ \\
\hline Chitin $^{a}$ & - & - & 5.0 & 3.0 & 100 \\
\hline 13 Sep & 1338 & 4.4 & 10.5 & 3.0 & 100 \\
\hline $20 \mathrm{Sep}$ & 389 & 1.3 & 1.5 & $<0.1$ & 100 \\
\hline \multicolumn{6}{|c|}{$\begin{array}{l}\text { a Chitin particles (Sigma) added to filtered seawater } \\
{ }^{b} \text { Samples were treated with chitinase for } 3 \mathrm{~h}\end{array}$} \\
\hline
\end{tabular}



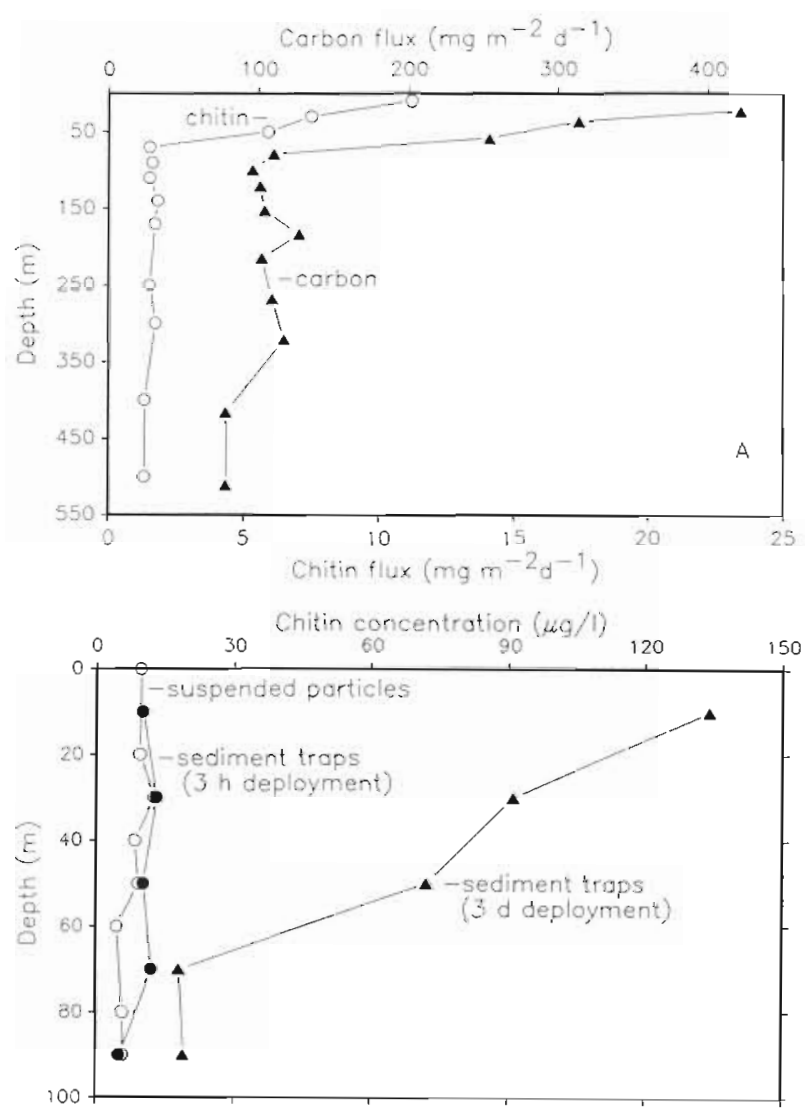

Fig. 6. Chitin concentrations (measured with ${ }^{3} \mathrm{H}-\mathrm{WGA}$ ) in sediment traps and the suspended chitin concentrations in the surrounding waters from the Gulf of Alaska during Auguist 1988

rescence microscopy. Most particles that were intensely stained with FITC-WGA were amorphous detritus without an obvious origin. In some samples, the chitinous cell walls of what appeared to be singlecelled yeasts or ascospores and filamentous fungi (S. Y. Newell pers. comm.) stained intensely. Pellets from copepods well-fed in the laboratory were large and stained intensely with FITC-WGA. Cellulose and clay (kaolin) added to samples did not stain with FITCWGA, nor did naturally-occurring bacteria.

\section{DISCUSSION}

Little is known about the role of chitin in carbon and nitrogen cycles, even though chitin is thought to be very abundant in marine environments. This absence of information is in part due to the lack, previous to this study, of a method to measure chitin at ambient concentrations. Our experiments on competitive inhibition and chitinase degradation indicate that the succinylated form of WGA is specific for chitin in seawater and can be used to measure chitin at ambient concen-

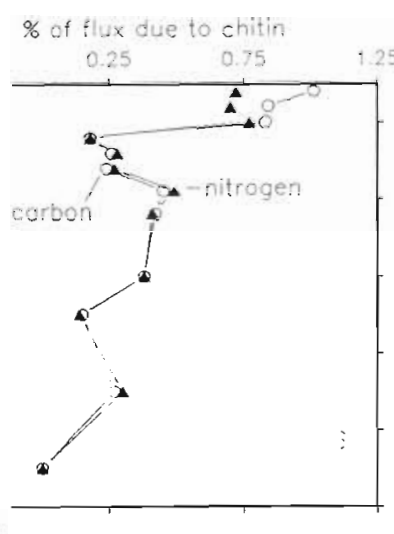

Fig. 5. Chitin flux in the subarctic Pacific during August 1988. (A) Vertical flux of chitin (measured with ${ }^{3}$ H-WGA) and carbon. (B) Percent of carbon and nitrogen flux that can be accounted for by the chitin flux

trations. Common components of seawater samples, such as cellulose, clay, and bacteria, did not interfere with the assay. Epifluorescence microscopy with FITCWGA confirmed that the lectin was binding specifically to chitin-containing particles.

The WGA assay can be used to measure only chitin that is not blocked or sterically-hindered by other macromolecules. Extraction of the sample with TCA or other solvents (e.g. chloroform and methanol to extract lipds) may remove some interfering macromolecules, although we found that the measured chitin concentration in Delaware Bay samples did not change after TCA extraction. Another potential problem with this assay is that WGA can only bind to particle surfaces. As a consequence, the WGA assay may underestimate the true chitin amount. However, this is a problem only if the size distribution of chitin particles used in standard curves differs greatly from that of the particles in samples. The chitin used for our standard curves ranged in size from 2 to $30 \mu \mathrm{m}$ (diameter). This size range is likely to include the most abundant particles in seawater samples (Sheldon \& Sutcliffe 1969).

Chitin concentrations as measured by the WGA method ranged from 4 to $21 \mathrm{ug} \mathrm{l}^{-1}$ near the mouth of the Delaware Bay at Roosevelt Inlet. Some of the chitin may be produced by the diatoms Skeletonema costatum and Thalassiosira sp., which are the dominant phytoplankton species in the Delaware Bay (Pennock \& Sharp 1986). In the lower estuary, a phytoplankton bloom occurs annually in September (areal production ca $1500 \mathrm{mg} \mathrm{C} \mathrm{m}^{-2} \mathrm{~d}^{-1}$ ) followed by a period of lower primary production (ca $100 \mathrm{mg} \mathrm{C} \mathrm{m}^{-2} \mathrm{~d}^{-1}$ ) in November and December (Pennock \& Sharp 1986). The decrease in chitin concentrations from 21 to $4 \mathrm{ug} \mathrm{l}^{-1}$ reflects this seasonal decline in primary production. Another potentially important source of chitin is copepods whose carapaces, exuviae, and fecal pellets contain substantial amounts of chitin. Copepods are abundant in the Delaware Bay (Herman et al. 1983)

Chitin concentrations in the Delaware Bay $(4$ to $21 \mathrm{ug}$ 
$1^{-1}$ ) were similar to those of the subarctic Pacific ( 4 to $10 \mu \mathrm{g} \mathrm{l}^{-1}$ ). If chitin were refractory, chitin concentrations would be expected to be higher in the Delaware Bay Estuary than in the subarctic Pacific because of the higher production of the estuary. In contrast, chitin may be like other compounds used readily by heterotrophic bacteria, for example dissolved free amino acids. The concentration of these compounds in the highly productive Delaware Bay is similar to that found in the less productive subarctic Pacific (Kirchman \& Hoch 1987, Coffin 1989, Kirchman et al. 1989). This suggests that chitin may be degraded more rapidly than might be expected for a structural carbohydrate.

Chitin concentrations were also measured in sediment trap samples taken from the subarctic Pacific. The large decrease in chitin flux from $11.2 \mathrm{mg} \mathrm{m}^{-2} \mathrm{~d}^{-1}$ at $10 \mathrm{~m}$ to $1.5 \mathrm{mg} \mathrm{m}^{-2} \mathrm{~d}^{-1}$ at $70 \mathrm{~m}$ suggests that chitin is quickly degraded or transformed to some other compound not measured by the WGA assay. The turnover time for the chitin pool was $119 \mathrm{~d}$ in these surface waters (ca $12^{\circ} \mathrm{C}$ in 0 to $50 \mathrm{~m}$ ), based on the chitin flux and concentrations of suspended chitin. This turnover time is similar to the turnover time $\left(140 \mathrm{~d}\right.$ at $\left.15^{\circ} \mathrm{C}\right)$ calculated by Seki (1965) whose estimate was based on chitin degradation by bacteria and the probable number of chitinolytic bacteria in the water column. Below $70 \mathrm{~m}$, the chitin flux remained constant at about $1.5 \mathrm{mg} \mathrm{m}^{-2} \mathrm{~d}^{-1}$. Chitan production is probably highest in the upper water column because primary production (including diatoms; Booth et al. 1988) and zooplankton abundance and feeding are highest there.

Chitinase treatment of the sediment trap sample from the station with low primary production did not prevent WGA binding. The WGA may be measuring materials not easily degraded by chitinase, perhaps because of the presence of protein-free chitin (chitan), such as that produced by diatoms. Chitan is more slowly degraded by chitinase because it is not hydrolyzed by endochitinase (Lindsay \& Gooday 1985). Endochitinase cleaves bonds randomly along the chitin strand to form loose ends that are hydrolyzable by exochitinase (Berger \& Reynolds 1958). Degradation of these samples may require extended chitinase degradation or chemical pretreatment to increase enzymatic hydrolysis. Another possibility is that the chitin is partially degraded to some form that is not easily hydrolyzed by chitinase but still binds with WGA. Chitin produced by marine invertebrates is cross-linked with proteins (Austin et al. 1981, Brine \& Austin 1981). Chitinolytic marine bacteria could degrade and utilize the portions of the chitin fibrils that were susceptible to hydrolysis by chitinase. The undegraded chitin that sinks to the ocean depths may be heavily cross-linked which impedes further degradation by bacterial proteases and chitinases. This may partially explain the large turnover times $(>2000 \mathrm{~d}$ ) for the chitin pool below the mixed layer.

The vertical fiux of chitin was 0.5 to $1.1 \%$ of the total carbon and nitrogen flux. Muller et al. (1986) observed that the percent of total carbon flux contributed by glucosamine was greater in deep waters (3.6\%) than in surface waters $(1.9 \%)$. One problem, however, with the estimates of Muller et al. (1986) is that bacteria could colonize particles or grow in sediment traps (Ducklow et al. 1982, Karl et al. 1984). Cell walls from these bacteria would contribute to the glucosamine measured by Muller et al. (1986). In contrast, bacteria do not interfere with the WGA assay. According to either approach, the chitin flux is relatively small, but the material associated with the chitin (e.g. protein and carbohydrates in fecal pellets) may still be a large fraction of the total carbon and nitrogen flux.

We recognize that some of the chitin flux may be the result of zooplankton swimming into the traps. However, the samples were filtered with a $500 \mu \mathrm{m}$ mesh prior to assay for chitin. We suspect that most of the chitin is associated with detritus. In future studies, the WGA method may be useful in examining more carefully the 'swimmer' problem in sediment traps. The amount of WGA bound to detritus can be estimated by epifluorescence microscopy and compared with the total chitin concentration measured for the sample. One could then calculate the contribution of zooplankton that swam into the traps relative to the chitin contributed by detritus. Such a comparison may be a relatively sensitive method for measuring the contamination of sediment trap material with zooplankton swimmers and may ultimately lead to more accurate carbon and nitrogen flux measurements.

Acknowledgements. We thank $M$. Dagg, $T$ Nagata, and M.-O. Samuelsson for their critical comments and S. Y Newell for examining the samples stained with FITC-WGA. R. G. Kell, M.P. Hoch, and J.M. Montgomery provided technical assistance and valuable discussions. $M$. Roman and $C$. Miller provided a generous supply of Acartia tonsi and technical support. We also thank 2 anonymous reviewers for comments that improved the manuscript. The research was supported by ONR contract N00014-87-K-0108 and NSF grant OCE8614170 (to D.L.K.) and NSF grant OCE-8919557 (to N.A.W.).

\section{LITERATURE CITED}

Allen, A. K., Neuberger, A., Sharon, N. (1973). The purification, composition and specificity of wheat germ agglutinin. J. Biochem. 131: 155-162

Austin, P. R., Brine, C. J., Castle, J. E., Zikakis, J. P. (1981). Chitin: new facets of research. Science 212: 749-753

Berger, L. R., Reynolds, D. M. (1958). The chitinase system of a strain of Streptomyces griseus. Biochem. Biophys. Acta 29: $522-534$ 
Booth, B. C., Lewin, J., Lorenzen, C. J. (1988). Spring and summer growth rates of subarctic Pacific phytoplankton assemblages determined from carbon uptake and cell volumes estimated using epifluorescence microscopy. Mar. Biol. 98: 287-298

Brine, C. J., Austin, P. R. (1981). Chitin isolates: species variation in residual amino acids. Comp. Biochem. Physiol 70B: $173-178$

Coffin, R. B. (1989). Bacterial uptake of dissolved free and combined amino acids in estuarine waters. Limnol. Oceanogr 34 (3): 531-542

Ducklow, H. W., Kirchman, D. L., Rowe, G. T (1982). Production and vertical flux of attached bacteria in the Hudson River plume of the New York Bight as studied with floating sediment traps. Appl. environ. Microbiol. 43: 769-776

Fowler, S. W., Knauer, G. A. (1986). Role of large particles in the transport of elements and organic compounds through the oceanic water column. Prog. Oceanogr. 16: 147-194

Greven, H., Peters, W (1986). Localization of chitin in the cuticle of Tardigrada using wheat germ agglutinin-gold conjugate as a specific electron-dense marker. Tissue Cell 18 (2): 297-304

Herman, S. S., Hargreaves, B. R., Lutz, R. A., Fritz, L. W. Epifanio, C. E. (1983). Zooplankton and parabenthos. In: Sharp, J. H. (ed.) The Delaware Estuary: research as background for estuarine management and development. University of Delaware, Lewes, Delaware, p. 157-168

Johnstone, J. (1908). Conditions of life in the sea. University Press, Cambridge

Jeuniaux Ch., Voss-Foucart, M. F., Bussers, J. C. (1982). Preliminary results on chitin biomass in some benthic marine biocenoses. In: Hirano, S, Tokura, S. (eds.) Chitin and chitosan. Proceedings of the second international conference on chitin and chitosan, July 12-14, 1982. Japanese Society of chitin and chitosan, Sapporo, p. 200-204

Karl, D. M., Knauer, G. A., Martin., J. H., Ward, B. B. (1984) Bacterial chemolithotrophy in the ocean is associated with sinking particles. Nature, Lond. 309: 54-56

Kirchman, D. L., Hoch, M. P. (1988). Bacterial production in the Delaware Bay estuary estimation from thymidine and leucine incorporation rates. Mar. Ecol. Prog. Ser. 45: $169-178$

Kirchman, D. L., Keil, R. G., Wheeler, P. A. (1989). The effect of amino acids on ammonium utilization and regeneration by heterotrophic bacteria in the subarctic Pacific. Deep Sea Res. 36 (11A): 1763-1776

Knauer, G. A., Karl, D. M., Martin, J. H., Hunter, C. N. (1984) In situ effects of selected preservatives on total carbon. nitrogen and metals collected in sediment traps. J. mar Res. 42: 445-462

Lindsay, G. J. H., Gooday, G. W. (1985). Action of chitinase on spines of the diatom Thalassiosira fluviatilis. Carbohyd. Poly. 5: 131-140

Lorenzen, C. J., Welschmeyer, N. A., Copping, A. E., Vernet, M. (1983). Sinking rates of organic particles. Limnol. Oceanogr $28(4): 766-769$

McLachlan, J., McInnes, A. G., Falk, M. (1965). Studies on the

This article was presented by Dr S. Y. Newell, Sapelo Island, Georgia, USA chitan (chitin, poly- $\mathrm{N}$-acetylglucosamine) fibers of the diatom Thalassiosira fluviatilis Hustedt. I. Production and isolation of chitan fibers. Can. J. Bot. 43: 707-713

Monsigny, M., Sene, C., Obrenovitch, A., Roche, A. C. Delmotte, F., Boschetti, E. (1979). Properties of succinylated wheat-germ agglutinin. Eur. J. Biochem. 98: 39-45

Muller, P. J., Suess, E., Ungerer, C. A. (1986). Amino acids and sugars of surface particulate and sediment trap material from waters of the Scotia Sea. Deep Sea Res. 33 (6): 819-838

Parsons, I. R., Maita, Y., Lalli, C. M. (1984). A manual of chemical and biological methods for seawater analysis Pergamon Press, New York

Pennock, J. R., Sharp, J. H. (1986). Phytoplankton production in the Delaware Estuary: temporal and spatial variability. Mar Ecol. Prog. Ser. 34: 143-155

Peters, W. Latka, I. (1986). Electron microscopic localization of chitin using colloidal gold labelled with wheat germ agglutinin. Histochem. 84: 155-160

Poulicek, M., Jeuniaux, Ch. (1982). Biomass and biodegradation of mollusk shell chitin in some marine sediments. In: Hirano, S., Tokura, S. (eds.) Chitin and chitosan. Proceedings of the second international conference on chitin and chitosan, July 12-14, 1982. Japanese Society of chitin and chitosan, Sapporo, p. 196-199

Reissig, J. L., Strominger, J. L., Leloir, L. F. (1955). A modified colorimetric method for the estimation of $\mathrm{N}$-acetylamino sugars. J. biol. Chem. 217: 959-966

Roth, J. (1978). The biological functions of the lectins, 2. Wheat Germ Agglutinin. In: Roth, J. (ed.) The lectins: molecular probes in cell biology and membrane research. VEB Gustav Fischer Verlag, Jena, p. 21-23

Seki, H. (1965). Microbiological studies on the decomposition of chitin in marine environments. IX. Rough estimation on chitin decomposition in the ocean. J. oceanogr. Soc. Jap. 21. 261-269

Sharon, N., Lis, H. (1972). Lectins: cell-agglutinating and sugar-specific proteins. Science 177: 949-959

Sheldon, R. W., Sutcliffe, W. H. Jr (1969). Retention of marine particles by screens and filters. Limnol. Oceanogr. 14: $441-444$

Smucker, R. A., Dawson, R. (1986). Products of photosynthesis by marine phytoplankton: chitin in TCA 'protein' precipitates. J. exp. mar Biol. Ecol. 104: 143-152

Tack, B. F., Dean, J., Eilat, D., Lorenz, P. E., Schechter, A. (1980). Tritium labelling of proteins to high specific activity by reductive methylation. J. biol. Chem. 255: 8842-8847

Tronchin, G., Poulain, D., Herbaut, J. Biguet, J. (1981). Localization of chitin in the cell wall of Candida albicans by means of wheat germ agglutinin; fluorescence and ultrastructural studies. Eur J. Cell Biol. 26: 121-128

Welschmeyer, N. A., Lorenzen, C. J. (1985). Chlorophyll budgets: zooplankton grazing and phytoplankton growth in a temperate fjord and the Central Pacific Gyres. Limnol. Oceanogr. 30 (1): 1-21

Yoshikoshi, K., Ko, Y (1988). Structure and function of the peritrophic membranes of copepods. Nippon Suisan Gakk. 54 (7): $1077-1082$

Manuscript first received: December 18, 1989

Revised version accepted: April 26, 1990 